\title{
Effects of the Aqueous Extracts of Rhodamnia cinerea on Metabolic Indices and Sorbitol-Related Complications in Type 2 Diabetic Rats \\ (Kesan Ekstrak Akues Rhodamnia cinerea terhadap Indeks Metabolik dan Komplikasi Berkaitan Sorbitol dalam Tikus Diabetik Jenis 2)
}

\author{
MUSTAPHA UMAR IMAM, MAZNAH ISMAIL* \& SASIKALA M CHINNAPPAN
}

\begin{abstract}
There is growing interest in the use of plant bioresources for managing Type 2 diabetes. In this study, Rhodamnia cinerea, which is used traditionally to manage diseases in Malaysia, was explored for its antidiabetic effects. Type 2 diabetic rats were managed for 4 weeks using aqueous extract of $\mathrm{R}$. cinerea or quercetin. Weights and fasting glucose were measured weekly, while serum lipid profiles, insulin, antioxidant status, urea, creatinine and liver enzymes were assayed at the end. Sorbitol contents, antioxidant capacities and aldose reductase activities of the kidney, lens and sciatic nerve were also assessed. The results showed that the aqueous extract of $\mathrm{R}$. Cinerea mainly contained Myricitrin and it reduced glycemia $(\mathrm{p}>0.05)$, lipid profiles $(\mathrm{p}<0.05)$, F2-isoprostanes $(\mathrm{p}<0.05)$ and overall metabolic condition of type 2 diabetic rats. R. cinerea also attenuated sorbitol contents of the nerve $(\mathrm{p}<0.05)$ and kidney $(\mathrm{p}<0.05)$, partly through regulating the activity of aldose reductase ( $\mathrm{p}<0.05$ for nerve) and sorbitol dehydrogenase $(\mathrm{p}<0.05$ for kidney) in comparison with diabetic untreated group. Quercetin is a known aldose reductase inhibitor and can improve several metabolic indices related to Type 2 diabetes. In this study, the results of $\mathrm{R}$. cinerea were comparable to or better than those of quercetin, suggesting that R. cinerea extract can be a good candidate for managing Type 2 diabetes and its complications related to sorbitol accumulation.
\end{abstract}

Keywords: Aldose reductase; Rhodamnia cinerea; sorbitol; Type 2 diabetes

ABSTRAK

Terdapat minat yang meningkat dalam penggunaan sumber biologi tumbuhan untuk menguruskan Diabetes Jenis 2. Dalam kajian ini, Rhodamnia cinerea yang digunakan secara tradisi untuk menguruskan penyakit di Malaysia, telah dikaji untuk kesan antidiabetik. Tikus diabetik Jenis 2 dikendalikan selama 4 minggu menggunakan ekstrak akues R. cinerea atau quercetin. Berat dan paras glukosa puasa diukur setiap minggu, manakala profil serum lipid, insulin, status antioksidan, urea, kreatinin dan enzim hati telah dicerakin pada peringkat akhir. Kandungan sorbitol, kapasiti antioksidan dan aktiviti aldosa reduktase buah pinggang, kanta dan saraf sciatik turut dinilai. Hasil kajian menunjukkan bahawa ekstrak akues R. cinerea mengandungi Myricitrin dan memperbaiki glisemia ( $>0.05)$, profil lipid ( $\mathrm{p}<0.05)$, F2-isoprostanes $(\mathrm{p}<0.05)$ dan keadaan keseluruhan metabolik tikus Diabetes Jenis $2 \mathrm{R}$. cinerea juga mengurangkan kandungan sorbitol pada saraf $(\mathrm{p}<0.05)$ dan buah pinggang $(\mathrm{p}<0.05)$, sebahagiannya melalui kawal selia aktiviti aldosa reduktase $(\mathrm{p}<0.05$ untuk saraf) dan sorbitol dehydrogenase $(\mathrm{p}<0.05$ untuk buah pinggang) jika dibandingkan dengan kumpulan yang tidak dirawat. Quercetin adalah perencat aldosa reduktase yang dikenal pasti dan boleh meningkatkan beberapa indeks metabolik yang berkaitan Diabetes Jenis 2. Dalam kajian ini, hasil kajian R. cinerea adalah setanding dengan atau lebih baik daripada quercetin, justeru menunjukkan bahawa ekstrak R. cinerea boleh menjadi calon yang berpotensi untuk menguruskan Diabetes Jenis 2 dan komplikasi yang berkaitan dengan pengumpulan sorbitol.

Kata kunci: Aldosa reduktase; Diabetes Jenis 2; Rhodamnia cinerea; sorbitol

\section{INTRODUCTION}

There is a growing burden of Type 2 diabetes globally, which is driving the efforts for more effective ways to manage this disease. Moreover, currently available therapeutic options have so far fallen short of effectively managing the disease, due to side effects and narrow spectrum of activity that does not cover the multiple metabolic perturbations in this disease (Gurib-Fakim 2006; World Health Organization 2014). This has heightened interest in plant bioresources, which are seen as safer and more cost-effective options when compared with pharmaceutical agents. There is enough biodiversity in many countries to provide potential candidate plants with such medicinal potentials. Thus, there is an increasing drive to study plants that have hitherto been unexplored for their medicinal properties, which is what this study aimed to achieve. In particular, Malaysia is rich in biodiversity, and thus there has been an increasing drive to study plants with 
potential anti-diabetic and other beneficial effects, some of which are already used as traditional medicine, in order to provide evidence-based justification for their usage (Adam et al. 2011; Nasir et al. 2015; Rahim et al. 2014).

Rhodamnia cinerea, which belongs to the myrtle family, comprises of a group of rainforest trees and shrubs that are characterized by fleshy fruits (Govaerts et al. 2008). Their leaves are small and oblong, measuring around $2-7 \mathrm{~cm}$. Not much is known regarding the medicinal properties of $R$. cinerea, although its leaves and roots are used for traditional medicine (Keng 1990; Scott 1979). Additionally, we recently observed for the first time that the aqueous extract of the plant had antidiabetic potentials using in vitro and in vivo testing, which has been filed for patent (Gehling et al. 2015). Thus, we hypothesized that the aqueous extract of $R$. Cinerea could improve metabolic indices, organ-specific sorbitol contents and organ-specific aldose reductase activities in Type 2 diabetic rats, which was tested in this study.

\section{MATERIALS AND METHODS}

\section{MATERIALS}

Aldose reductase, F2-isoprostanes and Insulin ELISA kits were purchased from Elabscience Biotechnology Co. Ltd (Wuhan, China), while the deproteinization kit and total sorbitol content kit were purchased from Biovision (Mountain View, CA, USA) and Sigma Chemical Co. (St. Louis, Missouri, USA), respectively. RCL2 ${ }^{\circledR}$ Solution was purchased from ALPHELYS (Toulouse, France). Kits for biochemical analyses were purchased from RandoxLaboratories Ltd (Crumlin, County Antrim, UK). The sugar and starch powders were purchased from $\mathrm{R}$ \& S Marketing Sdn. Bhd. (Malaysia), while the Palm Oil, Nespray fortified milk powder and standard rat chow were purchased from Unilever (Malaysia), Nestle Manufacturing (Malaysia) and Specialty Feeds (TN, USA), respectively. Myricitrin reference standard $(\mathrm{C} 21 \mathrm{H} 20 \mathrm{O} 12$, CAS\# 17912-87-7) was purchased from ChromaDex (CA, USA). Other chemicals and quercetin were purchased from Sigma-Aldrich Chemical (USA) and Thermo Fisher Scientific (Massachusetts, USA).

\section{PLANT MATERIAL}

$R$. cinerea was purchased from RD Agro Herbs, Serdang, Malaysia, and authenticated (voucher specimen PID 170414-13) by Mr. Kamarudin Saleh from (Forest Research Institute Malaysia).

\section{SOLVENT EXTRACTION}

The collected plant was washed several times with running tap water followed by deionized water and the aerial parts (leaves and stems) were dried for 4 days. The dried material was cut into smaller pieces and passed through a mesh opening of $6.0 \mathrm{~mm}$ sieve (Retsch SM 100, Germany). They were then mixed with water in the ratio of $1: 10$ and heated using hot plate for $3 \mathrm{~h}$ at $100^{\circ} \mathrm{C}$. The mixtures were subsequently filtered through cotton wool (source and any spec) and the solvents were removed under reduced pressure (Rotavapor R210, Buchi, Switzerland) followed by spray drying (Buchi mini spray drier B-290, Switzerland). The dried crude extracts were stored at room temperature until further analysis.

\section{HPLC ANALYSIS OF EXTRACT}

HPLC analysis was performed using Agilent 1200 series linked with diode array detector (Agilent, Stevens Creek Blvd Santa Clara, USA). Chromatographic separations were performed on a Phenomenex Kinetex, Analytical column $(2.1 \times 150 \mathrm{~mm}, 1.7 \mu \mathrm{m})$. The mobile phase was composed of solvent (A) $0.1 \%$ formic acid in water and solvent (B) $0.1 \%$ formic acid in acetonitrile, with the respective solvent gradient: 95 and 5\% (0 min), 95 and 5\% (3 min), 80 and 20\% (8 min), 80 and $20 \%$ (16 min), 60 and $40 \%$ (22 min), 0 and $100 \%$ (25 min), 0 and 100\% (30 min) and 5 and $95 \%$ (33 $\mathrm{min}$ ). A flow rate of $0.3 \mathrm{~mL} / \mathrm{min}$ was used and $2 \mu \mathrm{L}$ of sample was injected. The samples and mobile phases were filtered through a $0.22 \mu \mathrm{m}$ Millipore filter, type GV (Millipore, Bedford, MA) prior to HPLC injection. Each extract and fraction was analyzed in three replicates. Myricitrin was identified and quantified by comparing its retention times with authenticated standard $(\mathrm{C} 21 \mathrm{H} 20 \mathrm{O} 12$, CAS\# 17912-87-7).

\section{ANIMAL HANDLING}

Approval for use of animals was sought from the Animal Care and Use Committee (ACUC) of the Faculty of Medicine and Health Sciences, Universiti Putra Malaysia (Project approval number: UPM/IACUC/UAP-R045/2013) and the set guidelines for the use of animals were strictly adhered to. The animals (Sprague dawley rats, 10 weeks old, weighing 200-250 g, n=25) were obtained from Veterinary Medicine Faculty, Universiti Putra Malaysia and placed in plastic cages (two per cage). They were given free access to normal rat chow and water for 2 weeks to acclimatize under controlled conditions $\left(25-30{ }^{\circ} \mathrm{C}\right.$, with a 12/12 h light/dark cycle). Thereafter, some rats (5 rats) were maintained on normal rat chow (normal group), while others were fed with high fat diet for 8 weeks and injected with streptozotocin (STZ) intraperitoneally (35 $\mathrm{mg} / \mathrm{kg}$ in sodium citrate buffer, $\mathrm{pH} 4.5$ ) to induce Type 2 diabetes (Imam \& Maznah 2013). The normal group also received $5 \mathrm{mmol} / \mathrm{L}$ of sodium citrate buffer, $\mathrm{pH} 4.5$ intraperitoneally. The diabetic rats (fasting plasma glucose of $\geq 250 \mathrm{mg} / \mathrm{dl}$ after 2 days of STZ) were divided into 4 groups ( $n=5$ ); diabetic untreated, $100 \mathrm{mg} / \mathrm{kg} /$ day $R$. cinerea extract, $200 \mathrm{mg} / \mathrm{kg} /$ day $R$. cinerea extract and quercetin $(10 \mathrm{mg} / \mathrm{kg} /$ day $)$ groups. Food intake was maintained at 30 $\mathrm{kcal} / 100 \mathrm{~g}$ body weight/day for 4 weeks after injection of STZ. Weekly measurements of weight and fasting blood glucose were made using a laboratory measuring scale and glucometer, respectively. During sacrifice, fasting blood and tissue samples (liver, kidney, lens and sciatic 
nerves) were collected for further tests. The tissues were immediately washed with ice-cold saline and stored in RCL2 ${ }^{\circledR}$ Solution (ALPHELYS, France) at $-80^{\circ} \mathrm{C}$, while the blood was centrifuged at $3000 \mathrm{rpm}$ for $10 \mathrm{~min}$ at $4^{\circ} \mathrm{C}$ to separate the serum.

\section{BIOCHEMICAL ANALYSES}

Kidney (urea and creatinine) and liver function (alanine transamine (ALT), aspartate transmaine (AST), alkaline phosphatase (ALP)) markers, and lipid profiles (total cholesterol (TC), low density lipoprotein (LDL), high density lipoprotein (HDL) and triglyceride (Trig)) were analyzed using Randox analytical kits according to manufacturer's instructions on Selectra XL Clinical Chemistry Analyzer (Vita Scientific, Dieren, The Netherlands).

\section{SERUM INSULIN AND F2-ISOPROSTANE AND LIVER ANTIOXIDANT STATUS}

Insulin and F2-isoprostane levels were measured from the serum samples collected, while liver samples were homogenized in cold phosphate buffered saline (1X PBS, pH 7.4), centrifuged at $7000 \mathrm{rpm}$ for $5 \mathrm{~min}$ and the supernatant used for total antioxidant status measurements using ELISA kits (Elabscience Biotechnology Co. Ltd, Wuhan, China) according to manufacturer's instructions. Absorbances were read on BioTeK Synergy H1 Hybrid Reader (BioTek Instruments Inc., Winooski, VT, USA), and the results were analyzed on www.myassays.com (insulin, $\mathrm{R}^{2}=0.9954$; F2-isoprostane, $\mathrm{R}^{2}=0.984$; Antioxidant status, $\mathrm{R}^{2}=0.94$ ).

\section{KIDNEY, LENS AND SCIATIC NERVE ANTIOXIDANT STATUS, TOTAL SORBITOL AND ALDOSE REDUCTASE}

Tissues stored in RCL2 solution (kidney, lens and nerve) were homogenized in cold phosphate buffered saline (1X PBS, pH 7.4), centrifuged at $7000 \mathrm{rpm}$ for $5 \mathrm{~min}$ and the supernatant used for total antioxidant status and aldose reductase activity. For sorbitol quantification, samples were deproteinized (Deproteinization kit, Biovision, Mountain View, CA, USA) prior to the assay. Tests were conducted using supernatants from the kidney, lens and nerves using the respective kits according to manufacturers' instructions.

\section{DATA ANALYSIS}

Data are presented as means $\pm \mathrm{SD}(n=5)$. The normality of the distribution of the data was confirmed using the Shapiro-wilk normality test prior to one-way analysis of variance (ANOVA) on SPSS 17.0 software (SPSS Inc., Chicago, IL, USA). Differences between means were considered significant when $p<0.05$.

\section{RESULTS AND DISCUSSION}

\section{R. CINEREA ATTENUATED WEIGHT GAIN AND HYPERGLYCEMIA}

The use of plants for managing diseases has been practised for a long time, although in recent years there is renewed interest in plant bioreseources due to concerns of side effects and cost of pharmaceutical agents (Gurib-Fakim 2006; Ismail \& Imam 2014). In this study, we explored the potential antidiabetic effects of $R$. cinerea. The results showed that there was progressive decrease in glycemia in the $R$. cinerea-treated groups, although no significant difference was observed compared to the diabetic untreated group (Table 1). Improved glycemia suggested that the plant extract is able to regulate the sustained chronic hyperglycemia, which is the hallmark of Type 2 diabetes (Stumvoll et al.2005), albeit not through improved insulin secretion (Table 2). Also, there was marked reduction in the weight of the diabetic untreated group $(p<0.05)$ between the baseline $311 \pm 20 \mathrm{~g}$ and week $4(257 \pm 38 \mathrm{~g})$ (Table 1), which can be attributed to gluconeogenesis. In Type 2 diabetes, when body cells cannot take up glucose from the

TABLE 1 . Blood glucose and body weight changes over 4 weeks of intervention

\begin{tabular}{|c|c|c|c|c|c|}
\hline \multirow[b]{2}{*}{ Rat groups } & \multicolumn{5}{|c|}{ Glucose $(\mathrm{mmol} / \mathrm{L})$} \\
\hline & Baseline & Week 1 & Week 2 & Week 3 & Week 4 \\
\hline R. cinerea $100 \mathrm{mg}$ & $18.7 \pm 3.3^{\mathrm{a}}$ & $14.6 \pm 0.6^{\mathrm{a}}$ & $16.5 \pm 1.7^{\mathrm{a}}$ & $16.7 \pm 4.9^{\mathrm{a}}$ & $15.1 \pm 3.1^{\mathrm{a}}$ \\
\hline R. cinerea $200 \mathrm{mg}$ & $17.9 \pm 3.6^{\mathrm{a}}$ & $18.3 \pm 2.0^{\mathrm{a}}$ & $16.8 \pm 1.2^{\mathrm{a}}$ & $16.2 \pm 1.6^{\mathrm{a}}$ & $16.2 \pm 1.6^{\mathrm{a}}$ \\
\hline Quercetin & $19.8 \pm 4.1^{\mathrm{a}}$ & $14.8 \pm 3.4^{\mathrm{a}}$ & $16.8 \pm 1.2^{\mathrm{a}}$ & $20.0 \pm 4.3^{\mathrm{a}}$ & $19.9 \pm 4.2^{\mathrm{a}}$ \\
\hline Diabetic untreated & $18.2 \pm 0.8^{\mathrm{a}}$ & $15.2 \pm 1.8^{\mathrm{a}}$ & $17.7 \pm 2.3^{\mathrm{a}}$ & $18.3 \pm 1.6^{\mathrm{a}}$ & $22.1 \pm 4.8^{\mathrm{a}}$ \\
\hline \multirow[t]{2}{*}{ Normal } & $4.7 \pm 0.5$ & $4.2 \pm 0.2$ & $5.3 \pm 1.3$ & $5.3 \pm 0.9$ & $5.2 \pm 0.8$ \\
\hline & \multicolumn{5}{|c|}{ Weight (g) } \\
\hline R. cinerea $100 \mathrm{mg}$ & $290 \pm 24$ & $261 \pm 21$ & $275 \pm 13$ & $272 \pm 38$ & $275 \pm 43$ \\
\hline R. cinerea $200 \mathrm{mg}$ & $297 \pm 37$ & $245 \pm 43$ & $249 \pm 48$ & $251 \pm 49$ & $244 \pm 37^{\mathrm{a}}$ \\
\hline Quercetin & $322 \pm 57$ & $302 \pm 44$ & $297 \pm 53$ & $303 \pm 52$ & $296 \pm 48$ \\
\hline Diabetic untreated & $311 \pm 21$ & $278 \pm 29$ & $261 \pm 39$ & $261 \pm 38$ & $258 \pm 38^{\mathrm{a}}$ \\
\hline Normal & $270 \pm 21$ & $288 \pm 24$ & $303 \pm 25$ & $316 \pm 25$ & $325 \pm 26$ \\
\hline
\end{tabular}

Data are mean $\pm \mathrm{SD}(n=5)$. The normal group was fed normal pellet throughout the intervention, while the diabetic untreated group (high fat diet $+35 \mathrm{mg} /$ $\mathrm{kg}$ streptozotocin) received high fat diet for 4 weeks The quercetin, $R$. cinerea $100 \mathrm{mg}$ and $R$. cinerea $200 \mathrm{mg}$ groups received qercetin (10 mg/kg/day) and $100 \mathrm{mg} / \mathrm{kg} /$ day and $200 \mathrm{mg} / \mathrm{kg} /$ day of aqueous extract of $R$. cinerea in addition to the high fat diet for 4 weeks after diabetes induction. ${ }^{\mathrm{a}}$ indicates statistical difference in comparison with the normal group for either glucose or weight measurements in each column $(p<0.05)$ 
blood due to insulin insensitivity, endogenous production of glucose in the liver is increase from fats and proteins broken down from body stores (Magnusson et al. 1992). This may explain the marginal decrease in body weight in the quercetin group since quercetin has been shown to inhibit gluconeogenesis (Gasparin et al. 2003). Although there was weight reduction in the $R$. cinerea groups, it may have been due to weight-reducing properties of the extracts as suggested by the high dose use in this study, which was able to reduce the weights beyond that of the diabetic untreated group.

\section{R. CINEREA IMPROVED LIPID PROFILES, OXIDATIVE STRESS, AND LIVER AND KIDNEY FUNCTIONS}

Lipid profile, liver and kidney functions are dysregulated in Type 2 diabetes (Imam et al. 2013,2012). In this study, $R$. cinerea significantly improved lipid profiles (Table 2) indicating that it may be able to prevent diabetes related cardiovascular diseases, which is an important cause of morbidity and mortality in Type 2 diabetes (Elkeles et al. 1998). Moreover, the worsened liver and kidney function were improved by $R$. cinerea (Table 2) also suggesting the ability of the extract to improve overall metabolic condition and its lack of toxicity in diabetes. The attenuation of oxidative stress in the liver as evidenced by reduced F2-isoprostane (Roberts \& Morrow 2000) in comparison with the untreated diabetic group (Table 2, $p<0.05$ ) further corroborates the improvement in overall metabolic condition of the diabetic rats as a result of feeding the $R$. cinerea extract.

\section{R. CINEREA ATTENUATED ALDOSE REDUCTASE ENZYME ACTIVITY}

Sorbitol contents (Table 2) of the lens, nerve and kidney were elevated in the untreated group, while quercetin, which is known to lower sorbitol levels (Kador et al. 1985), showed reduced levels in the lens and kidney $(p<0.05)$. $R$. cinerea extract also reduced the sorbitol contents, especially of the kidney and nerve $(p<0.05)$, which indicated that it may prevent sorbitol-related complications in type 2 diabetes including diabetic nephropathy and neuropathy. Because the activity of aldose reductase has been shown to influence sorbitol levels (Kador et al. 1985), we assayed the activities in the lens, kidney and nerve (Table 2). The results showed that the aldose reductase activities of the lens and nerve were significantly increased in the diabetic untreated group in comparison with the normal group, while the $R$. cinerea and quercetin groups attenuated these increases $(p<0.05)$. The reduced aldose reductase activities in the lens and nerves of the $R$. cinerea groups likely contributed to the lower sorbitol contents in these tissues (YabeNishimura 1998), although other factors including the metabolic flux due to blood glucose may have played a role in the case of the kidney (Gabbay 1975), which showed lower sorbitol content but not aldose reductase activity. Similarly, the ability of the extract to regulate oxidative stress in these tissues may have played a role in the regulation of sorbitol. It has been demonstrated that increased oxidative stress propagates the buildup of sorbitol and other complications in Type 2 diabetes (Dey \& Lakshmanan 2013; Rahimi et al. 2005) and the results from this study showed that the untreated diabetic control group had lower antioxidant capacities in the lens, kidney and nerve (Table 2), while the $R$. cinerea-treated groups had improved antioxidant capacities, although only those of the kidney were significant different $(p<0.05)$.

\section{HPLC BIOACTIVE IDENTIFICATION}

The active compound identified in the aqueous extract of $R$. cinerea was myricetrin $(1.013 \pm 0.003 \% \mathrm{w} / \mathrm{w}$ extract $)$, which is a flavonol rhamnoside of myricetin that is broken down to myricetin in the intestine (Smith \& Griffiths 1970), although some of it is converted to a myricetrin glycoside prior to absorption (Matsukawa et al.2012). Myricetrin has been shown to regulate intestinal glucose uptake (Postal et al. 2014) and weight gain (Maronpot et al. 2015), while its metabolite (myricetin) is widely acknowledged to have antidiabetic properties mediated via improvements in glycemia, weight and lipid profiles, antioxidation and aldose reductase inhibition (Li \& Ding 2012; Ong \& Khoo 1997), similar to the effects observed in this study.

In aggregate, our data showed that $R$. Cinerea could improve metabolic perturbations in Type 2 diabetic rats. Although some results were not significantly different between the $R$. cinerea-treated groups and the diabetic untreated group, perhaps longer treatment period could have produced more significant changes as indicted by the trend of improvements in the $R$. Cinerea groups. Therefore, $R$. cinerea can be a good candidate for diabetes management. Moreover, the inability of pharmaceutical agents to effectively prevent complications is the basis for the failure to effectively curb the burden of diabetes. These results suggested that the traditional use of $R$. cinerea for managing diseases may have been based on its ability to regulate multiple biochemical parameters as shown in the present study. Hence, $R$. cinerea has medicinal properties that can be developed into nutraceuticals for management of diabetes and its complications.

\section{CONCLUSION}

Type 2 diabetic rats treated with an aqueous extract of $R$. cinerea showed improved glycemia, lipid profiles and kidney and liver function markers. $R$. cinerea also regulated the activity aldose reductase and produced lower sorbitol contents of the nerve and kidney. Overall, the results of $R$. cinerea were comparable or even better than those of quercetin. Thus, $R$. cinerea extract can be a good candidate for the management of diabetic complications and other related metabolic disorders with lipid abnormalities and oxidative stress. However, there is need for long term studies to establish the translational implications of these findings. 


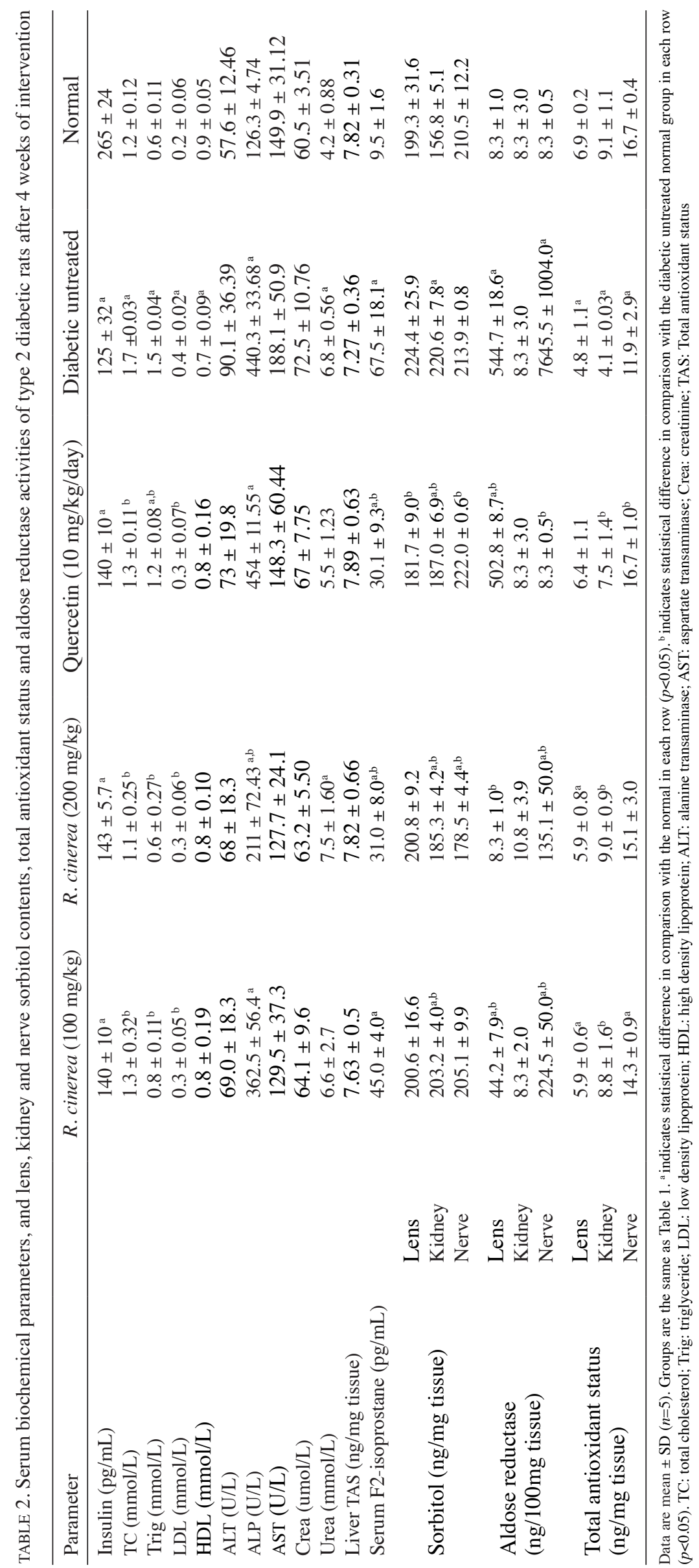




\section{ACKNOWLEDGEMENTS}

The authors thank the staff of the Laboratory of Molecular Biomedicine for their assistance with this study.

\section{REFERENCES}

Adam, Z., Ismail, A., Khamis, S., Mokhtar, M.H.M. \& Hamid, M. 2011.Antihyperglycemic activity of $F$. deltoidea ethanolic extract in normal rats. Sains Malaysiana 40(5): 489-495.

Dey, A. \& Lakshmanan, J. 2013. The role of antioxidants and other agents in alleviating hyperglycemia mediated oxidative stress and injury in liver. Food and Function 4(8): 1148-1184.

Elkeles, R.S., Diamond, J.R., Poulter, C., Dhanjil, S., Nicolaides, A.N., Mahmood, S., Richmond, W., Mather, H., Sharp, P., Feher, M.D. \& SENDCAP Study Group. 1998. Cardiovascular outcomes in type 2 diabetes: A double-blind placebo-controlled study of bezafibrate: The St. Mary's, Ealing, Northwick Park diabetes cardiovascular disease prevention (SENDCAP) study. Diabetes Care 21(4): 641648.

Gabbay, K.H. 1975. Hyperglycemia, polyol metabolism, and complications of diabetes mellitus. Annual Review of Medicine 26(1): 521-536.

Gasparin, F.R.S., Spitzner, F.L., Ishii-Iwamoto, E.L., Bracht, A. \& Constantin, J. 2003. Actions of quercetin on gluconeogenesis and glycolysis in rat liver. Xenobiotica 33(9): 903-911.

Gehling, M., Köpcke, B., Küper, T., Reinhardt, K., Reinemer, P., George, A., Chinnappan, S. \& Md. Akir, M.H. 2015. Extract Formulations of Rhodamnia Cinerea And Uses Thereof. U.S. Washington, DC: Patent and Trademark Office Patent No. $20,150,050,371$.

Govaerts, R., Sobral, N., Ashton, P., Barrie, F., Holst, B.K., Landrum, L.L., Matsumoto, K., Fernanda Mazine, F., Nic Lughadha, E., Proença, C. \& al. 2008. World Checklist of Myrtaceae. Royal Botanic Gardens, Kew: Kew Publishing.

Gurib-Fakim, A. 2006. Medicinal plants: Traditions of yesterday and drugs of tomorrow. Molecular Aspects of Medicine 27: $1-93$.

Imam, M.U. \& Maznah, I. 2013. Nutrigenomic effects of germinated brown rice and its bioactives on hepatic gluconeogenic genes in Type 2 diabetic rats and HEPG2 cells. Molecular Nutrition and Food Research 57(3): 401-411.

Imam, M.U., Maznah, I., Omar, A.R. \& Ithnin, H. 2013. The hypocholesterolemic effect of germinated brown rice involves the upregulation of the apolipoprotein A1 and low-density lipoprotein receptor genes. Journal of Diabetes Research 2013: Article ID. 134694.

Imam, M.U., Musa, A.S.N., Azmi, N.H. \& Maznah, I. 2012. Effects of white rice, brown rice and germinated brown rice on antioxidant status of Type 2 diabetic rats. International Journal of Molecular Sciences 13: 12952-12969.

Ismail, M. \& Imam, M.U. 2014. Plant bioresources and their nutrigenomic implications on health. In Novel Plant Bioresources: Applications in Food, Medicine and Cosmetics, edited by Gurib-Fakim, A. New Jersey: Wiley-Blackwell. pp 383-394.

Kador, P.F., Kinoshita, J.H. \& Sharpless, N.E. 1985. Aldose reductase inhibitors: A potential new class of agents for the pharmacological control of certain diabetic complications. Journal of Medicinal Chemistry 28(7): 841-849.

Keng, H. 1990. The Concise Flora of Singapore: Gymnosperms and Dicotyledons. Singapore: Singapore University Press.
Li, Y. \& Ding, Y. 2012. Minireview: Therapeutic potential of myricetin in diabetes mellitus. Food Science and Human Wellness 1(1): 19-25.

Magnusson, I., Rothman, D.L., Katz, L.D., Shulman, R.G. \& Shulman, G.I. 1992. Increased rate of gluconeogenesis in Type II diabetes mellitus. A 13C nuclear magnetic resonance study. Journal of Clinical Investigation 90(4): 1323-1327.

Maronpot, R.R., Koyanagi, M., Davis, J., Recio, L., Marbury, D., Boyle, M. \& Hayashi, S.M. 2015. Safety assessment and single-dose toxicokinetics of the flavouring agent, myricitrin, in Sprague Dawley rats. Food Additives \& Contaminants: Part A 32(11): 1799-1809.

Matsukawa, N., Matsumoto, M. \& Hara,H. 2012. Nondigestible saccharide enhances transcellular transport of myricetin glycosides in the small intestine of rats: A newly defined mechanism of flavonoid absorption. In Dietary Fiber and Health, edited by Cho, S. \& Almeida, N. New York: CRC Press. pp. 487-496.

Nasir, N.N.N.M., Khandaker, M.M. \& Mat, N. 2015. Bioactive compound and therapeutic value of the some Malaysia medicinal plants: A review. Journal of Agronomy 14(4): 319-330.

Ong, K.C. \& Khoo, H.E. 1997. Biological effects of myricetin. General Pharmacology 29: 121-126.

Postal, B.G., Guesser, S.M., Kappel, V.D., Ruani, A.P., Zamorano, N.S., de Campos, A.M., Reginatto, F.H., Pizzolatti, M.G., Hisayasu Suzuki, D.O. \& Barreto Silva, F.R.M. 2014. Mechanism of action of nutraceuticals on intestine to ameliorate glucose homeostasis: Follow-up studies by an in situ approach. Journal of Cell Science \& Therapy 5(3): 162. doi: 10.4172/2157-7013.1000162.

Rahim,A.A., Mohamad, J. \& Alias, Z. 2014. Antidiabetic activity of aqueous extract of Leptospermum flavescens in alloxan induced diabetic rats. Sains Malaysiana 43(9): 1295-1304.

Rahimi, R., Nikfar, S., Larijani, B. \& Abdollahi, M. 2005. A review on the role of antioxidants in the management of diabetes and its complications. Biomedicine \& Pharmacotherapy 59(7): 365-373.

Roberts, L.J. \& Morrow, J.D. 2000. Measurement of F 2 -isoprostanes as an index of oxidative stress in vivo. Free Radical Biology \& Medicine 28(4): 505-513.

Scott, A.J. 1979. A revision of Rhodamnia (Myrtaceae). Kew Bulletin 33(3): 429-459.

Stumvoll, M., Goldstein, B.J. \& van Haeften, T.W. 2005. Type 2 diabetes: Principles of pathogenesis and therapy. The Lancet 365: 1333-1346.

Smith, G.E. \& Griffiths, L.A. 1970. Metabolism of myricitrin and 3,4,5-trihydroxyphenylacetic acid. Biochemical Journal 118: 53P-54P.

World Health Organisation. 2014. Diabetes Fact. http://www.who. $\mathrm{int} /$ mediacentre/factsheets/fs312/en/index.html. Accessed on 6 October 2015.

Yabe-Nishimura, C. 1998. Aldose reductase in glucose toxicity: A potential target for the prevention of diabetic complications. Pharmacological Reviews 50(1): 21-34.

Mustapha Umar Imam \& Maznah Ismail*

Laboratory of Molecular Biomedicine, Institute of Bioscience

Universiti Putra Malaysia

43400 UPM Serdang, Selangor Darul Ehsan

Malaysia 
Maznah Ismail*

Department of Nutrition and Dietetics

Faculty of Medicine and Health Sciences

Universiti Putra Malaysia

43400 UPM Serdang, Selangor Darul Ehsan

Malaysia

Sasikala M Chinnappan

Biotropics Malaysia Berhad, Jalan Pantai Baharu

50672 Kuala Lumpur, Federal Territory

Malaysia
*Corresponding author; email: maznahis@upm.edu.my

Received: 26 November 2015

Accepted: 29 September 2016 